Sri Lanka J. Aquat. Sci. 13 (2008): 109 - 121

\title{
Diversity of mangrove crabs in Kadolkele, Negombo eatuary, Sri Lanka
}

\author{
S.H.R. PRIY ADARSHANI, S.C. JAY AMANNE* AND Y.N. \\ HIRIMUTHUGODA
}

National Aquatic Resources Research and Development Agency, Crow Island, Colombo 15, Sri Lanka

*Corresponding author (E-mail: sepalikauwu@yahoo.com)

\begin{abstract}
The present study was carried out from May 2001 to August 2001 to investigate the diversity, distribution and environmental interactions of mangrove crabs in the Kadolkele mangrove ecosystem associated with the Negombo estuary in the west coast of Sri Lanka. The data on diversity and abundance of crabs, salinity, $\mathrm{pH}$, organic carbon content, moisture and temperature of the soil, ambient air temperature and floral species of mangrove were collected from three $10 \mathrm{~m} \times 50 \mathrm{~m}$ belt transects laid perpendicular to the shore. Of the six species of crabs found in the study area, five were identified up to species level. They wereEpisesarma versicolor, Sesarma smithii, Sesarma guttatum, Metopograpsus thukuhar and Metopograpsus messor. This is the first record of Metopograpsus thukuhar and Sesarma guttatum in Sri Lanka. Diversity of crabs decreased with the increasing distance from the lagoon but the number of crabs present did not vary significantly $(p>0.05)$. The distribution of the crabs varied with the increasing distance from the lagoon.S. smithii and $M$. messor were distributed throughout the $50 \mathrm{~m}$ distance whileM. thukuhar and the unidentified species were restricted to $0-20 \mathrm{~m}$ and $0-10 \mathrm{~m}$ from the lagoon respectively.E. versicolor and S. guttatum were found towards the landward side $(25-50 \mathrm{~m})$. The distribution ofS. smithii showed a positive correlation $(\mathrm{p}<0.05)$ with the soil salinity and soil moisture content while M. thukuhar, S. guttatum and E. versicolor showed negative correlations (p $<0.05)$. All species exceptE. versicolor showed a positive correlation with soil organic carbon content $(\mathrm{p}<0.05) . M$. thukuhar showed a negative correlation with soil $\mathrm{pH}$ whileS. guttatum and S. smithii showed a positive correlation $(\mathrm{p}<0.05)$. M. thukuhar and unidentified juvenile crabs were found restricted to Rhizophora/Bruguiera zone, while $E$. versicolor and $S$. guttatum were confined to the Avicennia/Lumnitzera zone.
\end{abstract}




\section{Introduction}

Mangrove communities are considered as important elements in coastal ecosystems in the tropics because they are known to be highly productive systems, which function as nursery grounds to many commercially important marine species (Robertson 1991). In most countries of the tropics, crabs and molluscs dominate the mangrove forests. Smith et al. (1991) have shown that the sesarmid crabs occupy a keytone position in Australian mangrove forests. The potential role of crabs in cycling of material in mangrove communities and their ability in conserving nutrients within the forest are well recognized (Hatcher et al. 1989). Smith et al. (1991) showed that reductions in crab abundance had led to increased sulphide and ammonium concentrations in the soil and to reduced productivity and reproductive output by the mangroves. Bertness (1985) showed that the reduction of fiddler crab density for a single growing season decreased above ground production by $47 \%$ and burrowing by the crabs increased soil drainage, soil oxidation-reduction potential and thein situ decomposition of below ground plant debris.

Diversity of fauna in mangrove forests of Sri Lanka is so immense but is a relatively poorly dealt subject. The studies dealt with mangrove crabs in Sri Lanka are restricted to the study carried out by De Silva (1985) on fauna in five mangrove forests of Sri Lanka and the study done by Pinto (1984) on the crabs of Negombo estuary. It was felt that it is important to recognize the diversity of crabs in mangrove forests of Sri Lanka before initiating studies on their role in the mangrove forests. The present study was carried out to investigate the diversity and environmental interactions of mangrove crabs in the Kadolkele mangrove ecosystem, in the Negombo estuary. The distribution of crabs in different zones of mangroves was also investigated.

\section{Materials and Methods}

Kadolkele, a mangrove area belonging to the National Aquatic Resources Research and Development Agency, which is situated adjacent to the Negombo estuary in the Gampaha District, Sri Lanka, was selected as the study site. The area is about 10 ha in extent (Figure 1). Three belt transects each with a width of $10 \mathrm{~m}$ and a length of $50 \mathrm{~m}$ were laid perpendicular to the shoreline and were subdivided into $10 \mathrm{~m} \times 10 \mathrm{~m}$ plots. Each sampling plot had three systematic sampling units of $1 \mathrm{~m} \times 1 \mathrm{~m}$ in size, which ran diagonally (Figure 2). Sampling was carried out in alternate $10 \mathrm{~m} \times 10 \mathrm{~m}$ plot starting from lagoon shore as shown in Figure 2.

The crabs in each sampling unit were collected by digging the sampling area up to the water table until they are caught and picking them by hand. The number of crabs that belong to different species were recorded and identified up to species level using the taxonomic keys of Tirmizi et al. (1986). 


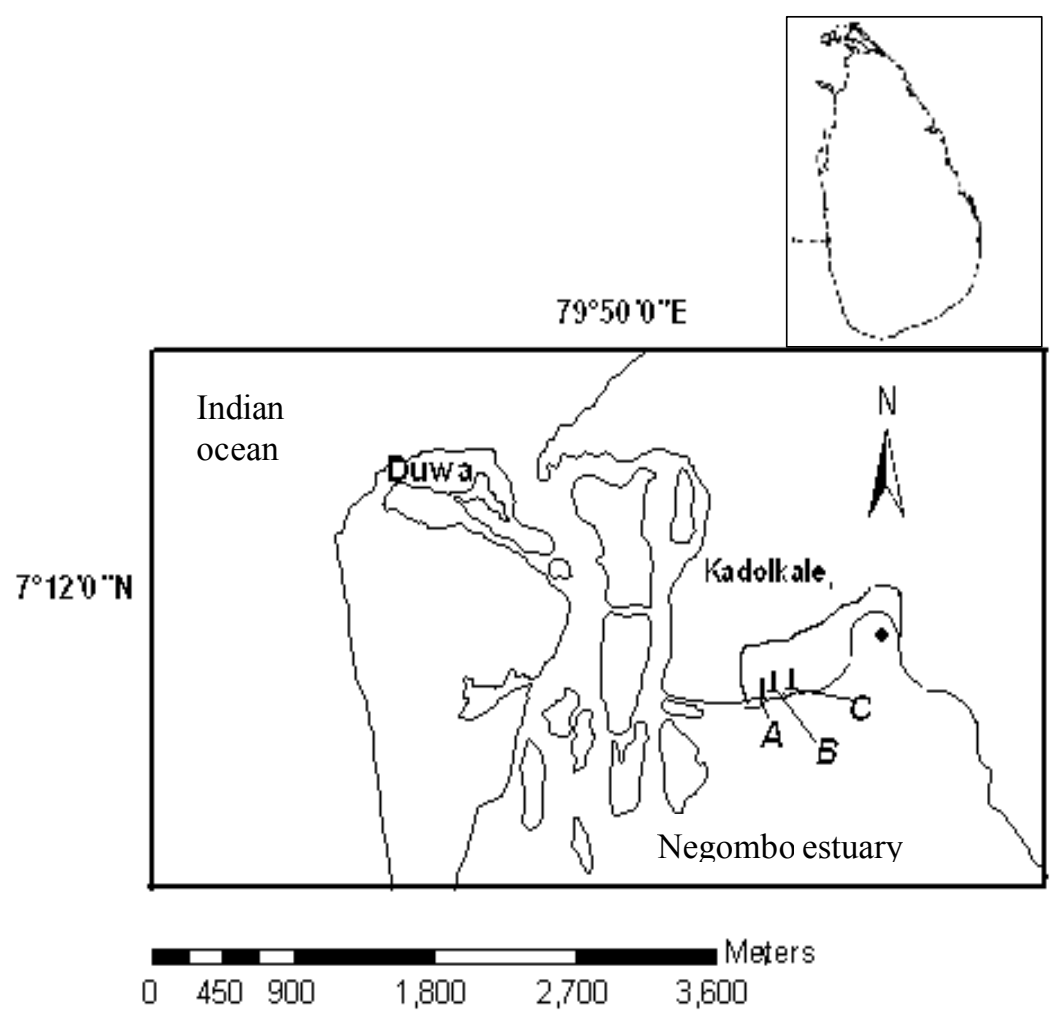

Figure 1. Location of the study area (A: Transect 1; B: Transect 2; C: Transect 3)

Soil samples were collected from each sampling plot and the environmental parameters, namely soil moisture content, soil temperature, soil salinity, soil $\mathrm{pH}$ and soil organic carbon content were measured. The soil moisture content was measured by oven drying a known weight of a soil sample at $105^{\circ} \mathrm{C}$ to a constant weight. Soil temperature was measured by inserting a glass mercury thermometer into the soil after making a hole with a wire and soil salinity was measured by a salinity refractometer (A TAGO model ) and soil $\mathrm{pH}$ was measured using a portable soil $\mathrm{pH}$ meter (Hach-Sension model). Water required for salinity measurements were collected by squeezing soil samples through a syringe. Soil organic carbon content was measured following the method described by Walkely and Black (1934).

Data were analyzed statistically using Complete Random Block Design (CRBD) of the SAS statistical package. Correlations between environmental parameters and crab abundance were analyzed using regression analysis in Excel Data Analysis tool. Shannon-Weiner diversity index (H') was calculated using the following formula given in $\operatorname{Zar}(1995)$.

$$
\mathrm{H}^{\prime}=-\sum \mathrm{P}_{\mathrm{i}} \log \left(\mathrm{P}_{\mathrm{i}}\right)
$$

Where $P_{i}$ is the proportion of the total count arising from the ${ }_{1}^{\text {th }}$ species. 


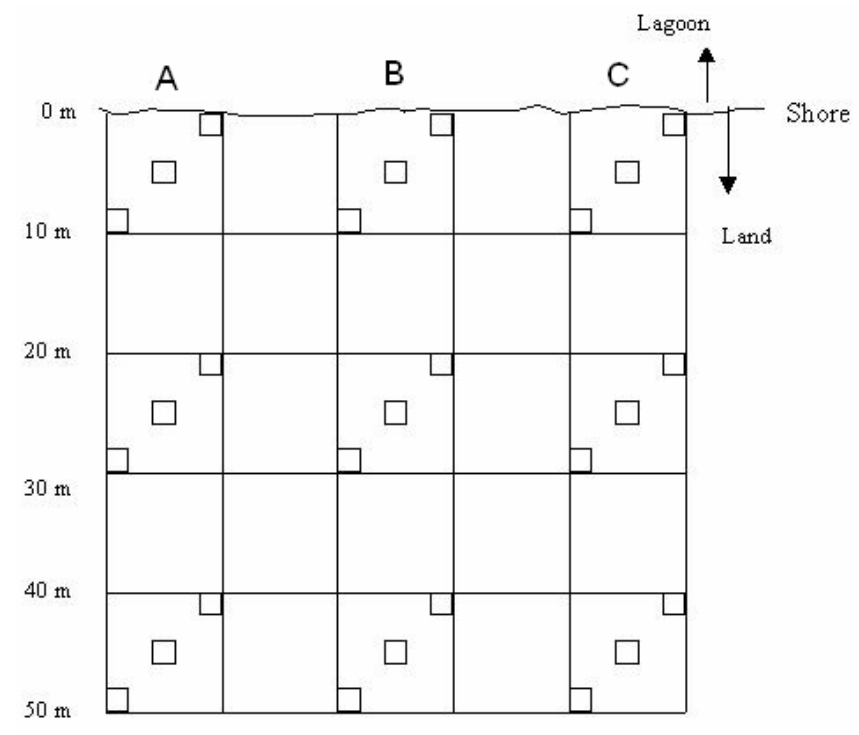

Figure 2. Diagrammatic representation of sampling units (A: Transect 1; B: Transect 2; C: Transect 3)

\section{Results}

Six crab species were identified from the selected area of study in the Kadolkele mangrove. All species belonged to family Grapsidae. Two of the species, S. guttatum and M. thukuhar have not been recorded previously from Sri Lanka. The morphological features of the two new species are shown in Figure 3.

The abundance of $S$. guttatum was significantly higher $(\mathrm{p}<0.05)$ in Transect A while no significant difference was observed in other crab species among transects. The crab species $M$. thukuhar, S. guttatum and E. versicolor showed a significant difference $(\mathrm{p}<0.05)$ with the distance from the edge of the water in the estuary while other three species did not show any significant differences $(\mathrm{p}>0.05)$.

The distribution of six species of crabs with reference to the distance from the estuary is shown in Figure 4.M. messor and S. smithii were distributed all along the transect whileM. thukuhar was restricted to a distance of $20 \mathrm{~m}$ from the estuary. Juvenile crabs of the unidentified species were also restricted to $0-10 \mathrm{~m}$ region of the transect. E. versicolor was observed more landwards and its distribution range was from $30-50 \mathrm{~m}$. 

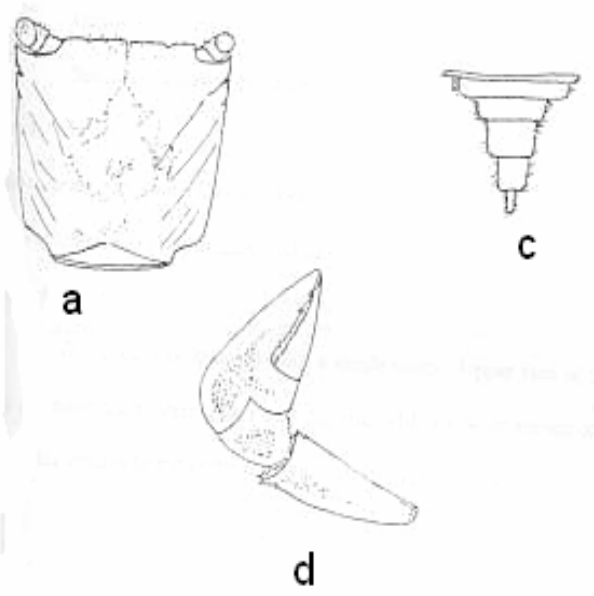

Metopograpsus thukuhar

C

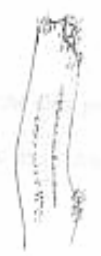

b

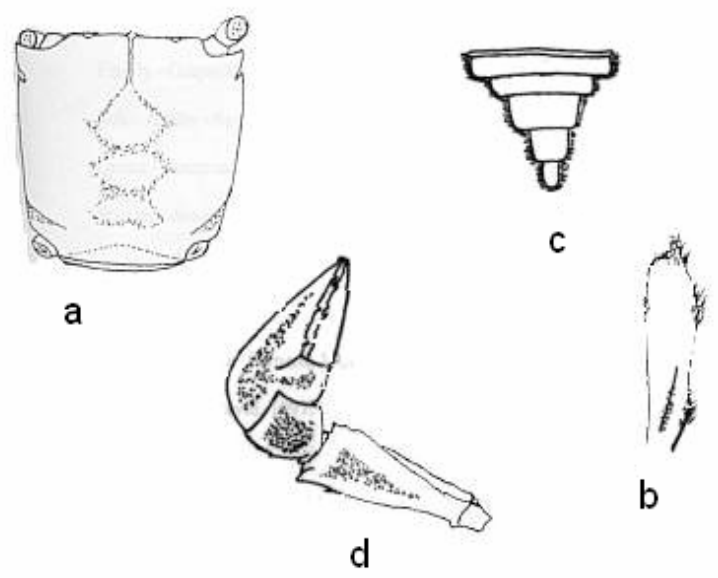

Sesarma guttatum

Figure 3. Morphological characteristics of Metopograpsus thukuhar and Sesarma guttatum a. Dorsal view of carapace b. Gonopod c. Abdomen of male d. Cheliped

The $\%$ frequency of the six species of crabs at each $5 \mathrm{~m}$ interval of the $50 \mathrm{~m}$ long transect is shown in Figure 5 and the percentage abundance of crabs with increasing distance from the estuary is shown in Figure 6. 


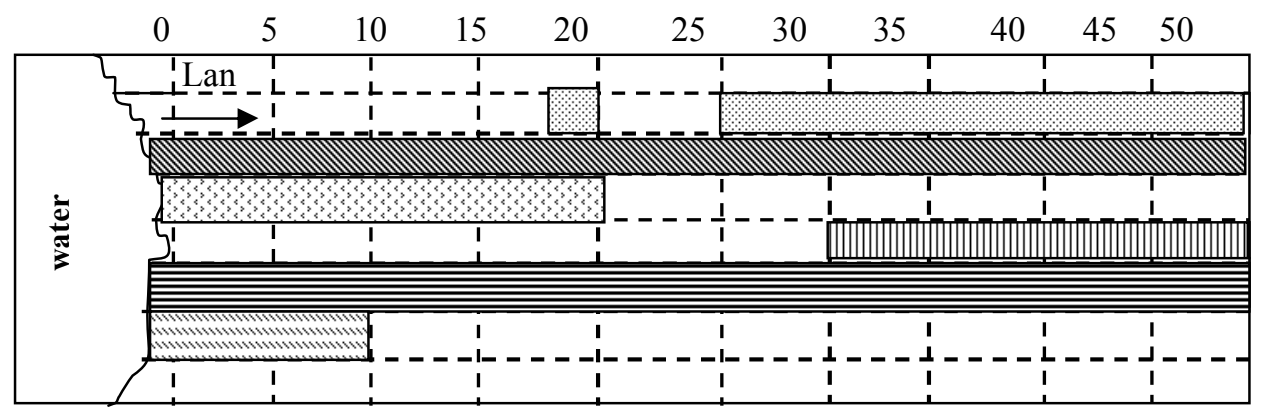

Distance from the estuary (m)

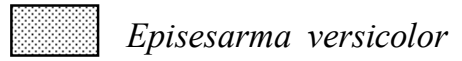

Sesarma smithii

Metopograpsus thukuhar
Sesarma guttatum

Metopograpsus messor

Unidentified species

Figure 4. The distribution of crab species with reference to the distance from the estuary.

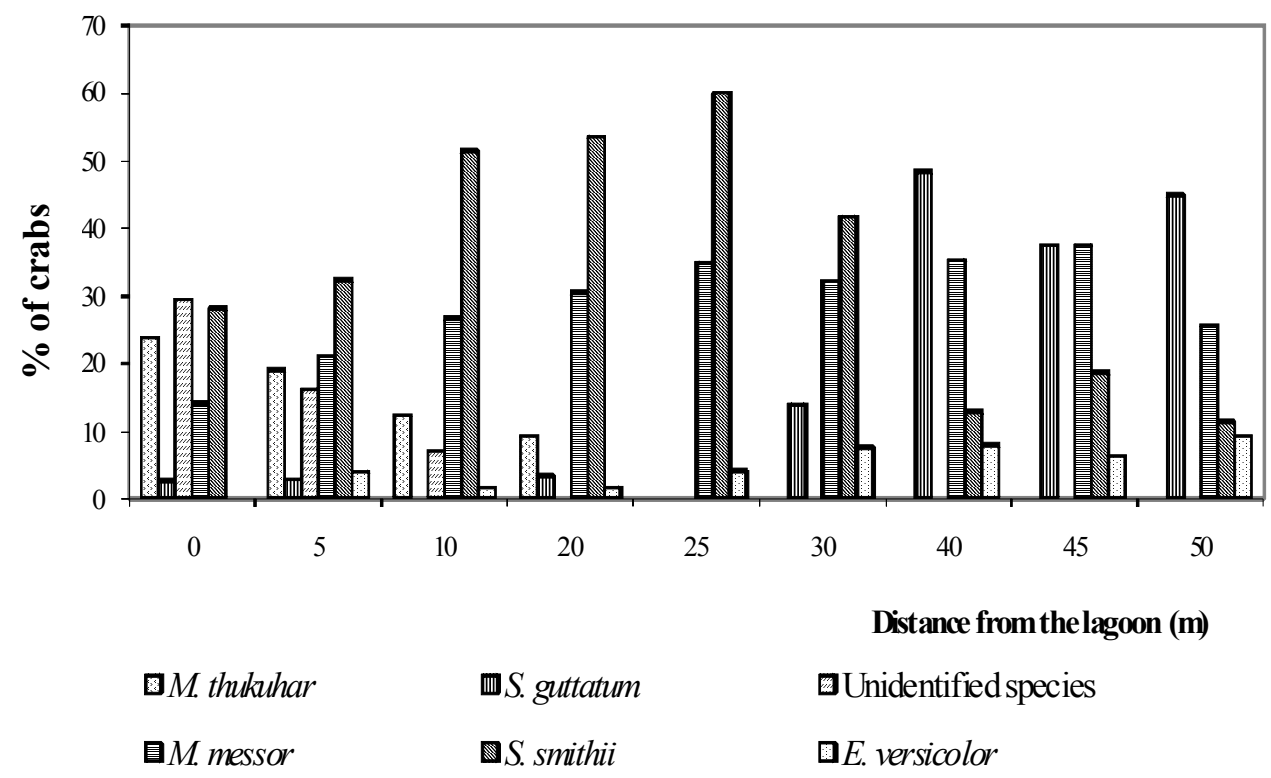

Figure 5. Mean values for the percentage frequency of the six crab species at each $5 \mathrm{~m}$ interval along the transects. 
S. smithii dominated the area between $5-30 \mathrm{~m}$ followed by $M$. messor. The distance of $40-50 \mathrm{~m}$ from the estuary was dominated by $S$. guttatum followed by M. messor. Juveniles of the unidentified crab species were dominant towards the first $10 \mathrm{~m}$ of the transects. As shown in Figure 6 , the highest number of crabs was recorded from 0-10 m distance and the lowest was recorded at $40 \mathrm{~m}$ distance.

Shannon Weiner diversity indices for the crabs in three habitats are given in Table 1. Highest diversity of the crabs was observed in the area closer to the estuary and the diversity decreased with the increasing distance from the estuary.

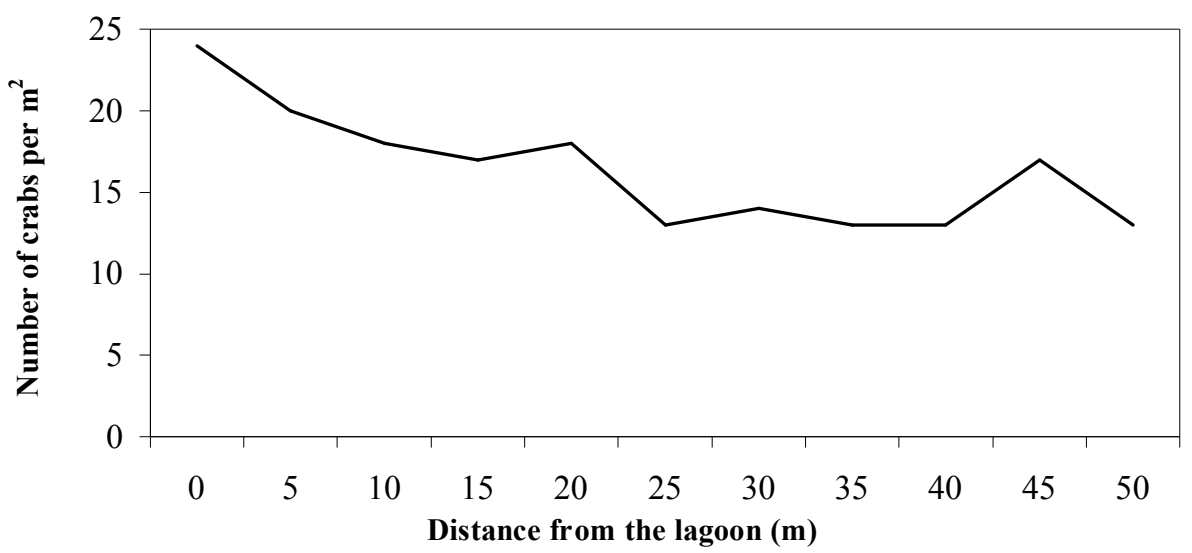

Figure 6. Variation in the abundance (number $/ \mathrm{m}^{2}$ ) of crabs with reference to the distance from the estuary.

Table 1. Shannon $\mathrm{W}$ einer diversity indices for crab species in three habitats

\begin{tabular}{|lc|}
\hline Distance from the Lagoon & Shannon-Wiener index $\left(\mathbf{H}^{\prime}\right)$ \\
\hline Lower area $(0-10 \mathrm{~m})$ & 0.68 \\
Middle area $(20-30 \mathrm{~m})$ & 0.55 \\
Upper area $(40-50 \mathrm{~m})$ & 0.52 \\
\hline
\end{tabular}

Figure 7(a) shows the variations in abundance of crab species with respect to the distance from the estuary. The variations in soil moisture content, soil organic carbon content, soil $\mathrm{pH}$ and soil salinity in relation to the distance from the estuary are given in Figure 7 (b). Table 2 indicates the significance of environmental factors on the abundance of six crab species 
in the Negombo lagoon. As shown in the Table 2,E. versicolor, $M$. thukuhar, and S. smithii did not show significant correlations with the environmental factors tested. M. messor showed significant positive correlations with soil moisture and soil $\mathrm{pH}$ while $S$. guttatum showed a significant negative correlation with soil salinity and a significant positive correlation with the soil temperature. Juvenile crabs of unidentified species showed a significant positive correlation with soil moisture.
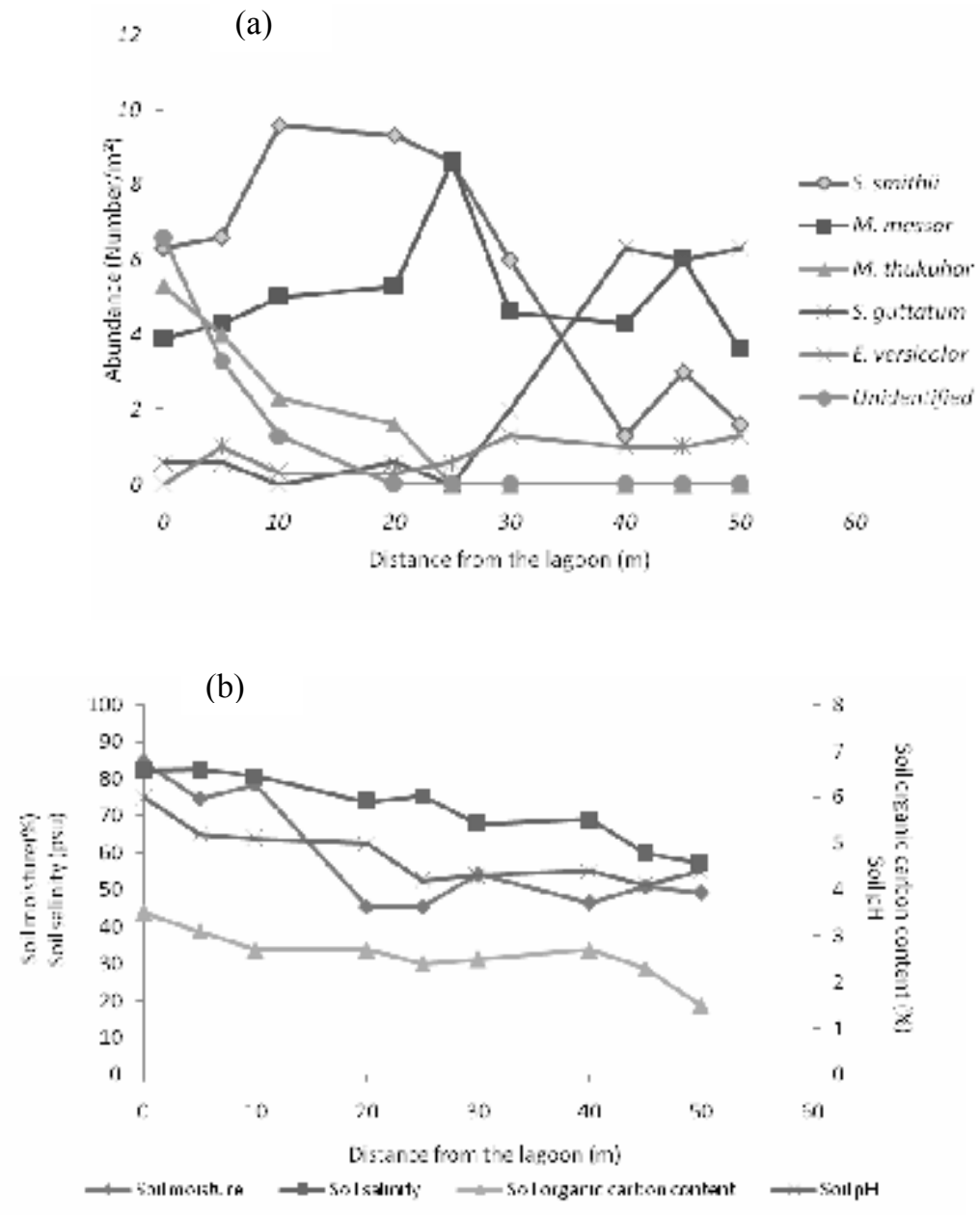

Figure 7 (a) The variation of the abundance of each species of crabs with respect to distance from the estuary (b) The variation of soil environmental parameters with respect to distance from the estuary. 
Table 2. Correlations* between environmental factors and the abundance of six crab species in the Negombo estuary

\begin{tabular}{|c|c|c|c|c|c|c|}
\hline Species & $\mathbf{n}$ & 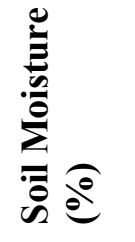 & 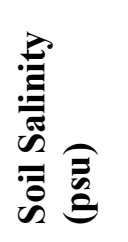 & 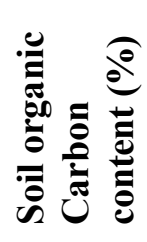 & = & $\frac{\overline{2}}{\overline{2}}$ \\
\hline E. versicolor & 21 & -0.49 & -0.45 & -0.40 & 0.24 & 0.22 \\
\hline M. messor & 138 & $0.67 * *$ & 0.45 & 0.58 & 0.12 & $0.69 * *$ \\
\hline M. thukuhar & 40 & -0.38 & -0.14 & 0.51 & 0.21 & -0.34 \\
\hline S. guttatum & 68 & -0.32 & $-0.76^{* *}$ & 0.33 & $0.68 * *$ & 0.68 \\
\hline S. smithii & 158 & 0.39 & 0.34 & 0.55 & 0.11 & 0.49 \\
\hline $\begin{array}{l}\text { Unidentified } \\
\text { Species }\end{array}$ & 34 & $0.63 * *$ & 0.15 & 0.37 & 0.09 & 0.32 \\
\hline
\end{tabular}

*Correlations are presented as $r$ values, $\mathrm{n}=$ total number of crabs

**Significant at $\mathrm{p}<0.05$

Distribution patterns of crabs with the zonation of mangrove flora showed that $M$. thukuhar and juveniles of unidentified species were abundant in the zone dominated by Rhizophora apiculata, R. mucronata and Bruguiera gymnorhiza (Figure 8). S. guttatum and E. versicolor were found mostly confined to the zone dominated byAvicennia marina and Lumnitzera racemosa

\section{Discussion}

Crabs and molluscs are the predominant animal groups of the mangrove ecosystems (Berry 1972; Jones 1984; Macintosh 1988) and they play a significant role in the structure and functioning of the ecosystems (Lee 1999). Number of crab species found in different climatic areas varies from one another. Ashton et al. (2003) have recorded 31 species of crab species from Sarawak mangrove in Indonesia. The number of species recorded in the present study is low compared to those recorded by Sasekumar (1974), Frith et al. (1976) and Ashton et al.(2003) in different study areas. This study has identified two crab species, namelySesarma guttatum and Metopograpsus thukuhar which were not recorded from Sri Lanka earlier. 


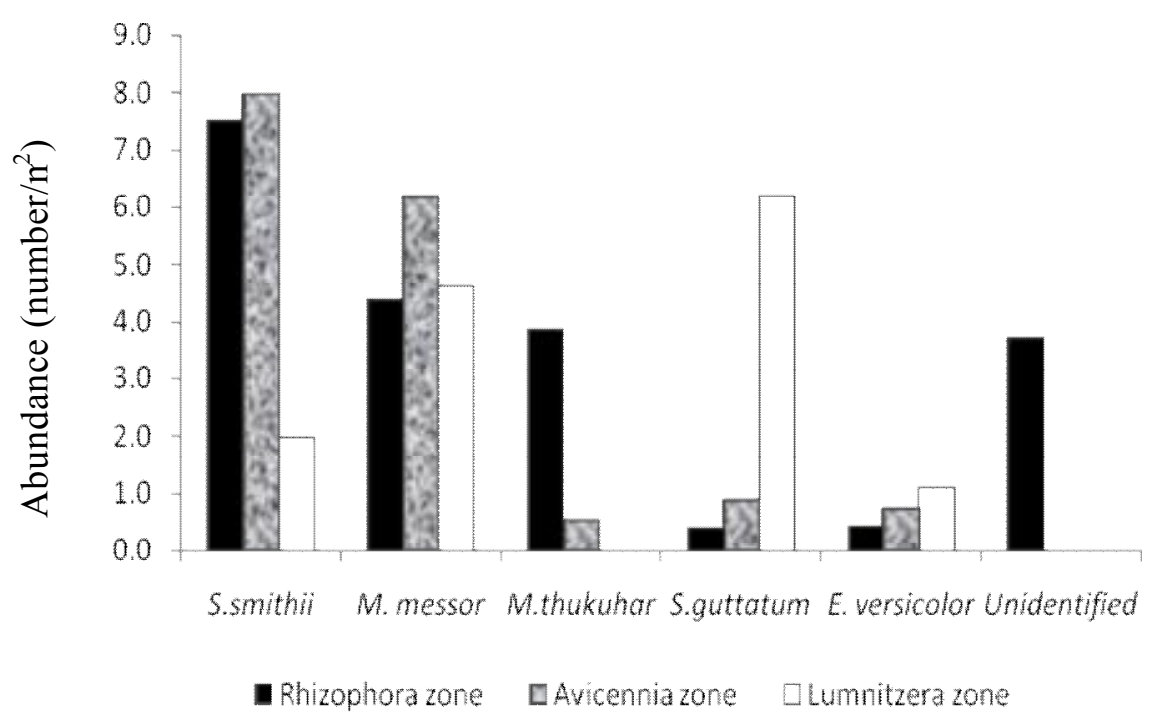

Figure 8. Distribution of crabs in three zones of mangrove flora

Abundance and distribution of mangrove crabs in relation to environmental parameters such as soil salinity, soil $\mathrm{pH}$, soil organic carbon content, soil sulphur content and soil nitrogen content has been described by previous workers (Sasekumar 1974; Macintosh 1984; Ashton 1999). Both qualitative (Berry 1963; Macnae 1968; Berry 1972; Macintosh 1984) and quantitative (Deekae and Henrion 1993; Guerreiro et al 1996) methods have been used to estimate the abundance of crabs in mangrove ecosystems and the dependence of mangrove crabs on the environmental conditions has been described. Salinity (Macintosh 1984), water content in the soil (Jones 1984), $\mathrm{pH}$, total percentage values for carbon, nitrogen and sulphur content of the soil (Ashton et al. 2003) and soil particle size are some of the factors which have shown correlations with the distribution and abundance of crabs. Macintosh (1984) found that the low-shore crab, Metaplax elegans could not tolerate salinities below 10\%, whereas Perisesarma onychophorum, inhabiting higher shore zones, could tolerate several days at $5 \%$. In the present study, the soil salinity varied between $60 \%$ to $80 \%$ and Episesarma versicolor and Sesarma guttatum preferred low salinity range (57 - 67\%) while the unidentified juvenile crab and Metopograpsus thukuhar preferred higher salinity (80 - 82\%).

Soil and water $\mathrm{pH}$ values also show correlations with the crab community structure (Ashton et al. 2003). Low-pH conditions can be detrimental to crabs because they depend on calcium carbonate formation for exoskeleton and shell building. Low- $\mathrm{pH}$ values can cause exterior 
exoskeleton and shell erosion in crustaceans and hence they tend to avoid such places (Plaziat 1984). Soil pH values in the upper zone of Kadolkele mangrove varied from 4.1 to 4.4 while it ranged between 5 and 6 in the lower zone. $M$. thukuhar and the juveniles of unidentified species were completely absent in the upper zone and the abundance of all crab species were found to be high in the lower area where soil $\mathrm{pH}$ value is higher compared to that of upper area showing that the crabs prefer higher soil $\mathrm{pH}$ levels. This is in agreement with the findings of Plaziat (1984). Sesarma guttatum and S. smithii have shown positive correlations with soil $\mathrm{pH}$ in the Kadolkele mangrove.

Carbon, nitrogen and sulphur contents of the soil are organic portions in the detritus and are important food sources. However, in humid areas with large amounts of detritus, most of the nitrogen and sulphur present is organic (Brady 1990). Many crabs have been observed feeding on the sediment (Macnae 1968). The bacteria and meio-fauna present in the sediment may also be a good source of nitrogen and sulphur for some macro-fauna species. Olafsson and Ndaro (1997) and Holguin et al.(2001) have observed positive correlations between crab biomass and soil nitrogen content which merit further attention in relation to the apparent importance of these soil organisms in the nutrition of common members of the crab fauna. Unfortunately, this study could not study the soil nitrogen contents due to lack of facilities, but positive correlations observed in abundance of all species of crabs with the soil carbon contents show their dependency on detritus based food web.

Presence of mangrove vegetation that provides a habitat structure and food for mangrove crabs is another factor determining their distribution (Hatcher et al. 1989; Lee 1998; Skilleter and Warren 2000; Ashton et al. 2003). Ashton et al (2003) showed that the crab community structure was correlated with the tree and seedling community structures indicating their importance in supporting crab diversity or vice versa. Some sesarmid species are known to feed on mangrove leaf litter and seedlings (Macnae 1968; Robertson 1986). Floral zonation in Kadolkele mangrove is closely associated with the zonation pattern described by Boaden and Seed (1985) in East Africa. In the present study it is evident that floral zonation has an influence on the spread of crab species. M. thukuhar and unidentified juvenile crabs were found restricted toRhizophora/Bruguiera zone, while $E$. versicolor and $S$. guttatum were confined to the Avicennia/Lumnitzera zone. Metopograpsus messor and $S$. smithii on the other hand could inhabit both zones.

A better understanding of the structure and functioning of the mangrove ecosystems are highly important for formulating strategies for conservation of these valuable ecosystems. In this study an attempt was made to initialize research on fauna of mangroves in Sri Lanka which receives a very little attention at present. Further research in this area is much needed and it is expected that the present study may throw a little light to future research on fauna of mangrove ecosystems in Sri Lanka. 


\section{References}

Ashton, E.C. 1999.

Biodiversity and Community Ecology of Mangrove Plants, Molluscs and Crustaceans in Two Mangrove Forests in Peninsular Malaysia in Relation to Local Management Practices. D.Phil. thesis, University of Y ork. 427 pp.

Ashton, E.C., D.J. Macintosh \& P.J. Hogarth 2003.

A baseline study of the diversity and community ecology of crabs and molluscan macrofauna in the Sematan mangrove forest, Sarawak, Malaysia. Journal of Tropical Ecology 19: 127-142.

Berry, A.J. 1963.

Faunal zonation in mangrove swamps. Bulletin of the National Museum State of Singapore 32:90-98.

Berry, A.J. 1972.

The natural history of W est Malaysian mangrove faunas. Malayan Nature Journal 25:135-162.

Bertness, M.D. 1985.

Fiddler crab regulation of Spartina alterniflora production on a New England salt marsh. Ecology 66:1042-1055.

Boadern, P.J.S. \& R. Seed 1985.

An Introduction to Coastal Ecology, Blackie, USA.

Brady, N.C. 1990.

The Nature and Properties of Soils. Macmillan Publishing Company, New Y ork.

Deekae, S.N. \& R. Henrion, 1993.

Multivariate analysis of species distribution a survey on occurrence of mangrove mollusks in the Bonny and New Calebar rivers of the Niger Delta. Acta Hydrochimica et Hydrobiologica 21: 273-279.

De Silva, K.H.G.M. 1985.

Life history of selected species of flora and fauna of the mangrove ecosystem, UNDP/UNESCO regional mangrove project, Bangkok, Thailand., October 1985.

Frith, D. W., R.Tantansiriwong, \& O. Bhatia 1976.

Zonation and abundance of macrofauna on a mangrove shore, Phuket Island. Phuket Marine Biological Centre Research Bulletin 10:1-37.

Guerreiro, J., S. Freitas, , P. Pereira, J. Paula, \& A. Macia, 1996.

Sediment macrobenthos of mangrove flats at Inhaca Island, Mozambique. Cahiers de Biologie Marine37:309-327.

B.G.Hatcher, R.E. Johannes \& A.I. Robertson 1989.

Review of research relevant to the conservation of shallow tropical marine ecosystems. Oceanography and Marine Biolology Annual Review 27:337-414.

Holguin, G., P.V azquez, \& Y . Bashan 2001. 
The role of sediment microorganisms in the productivity, conservation, and rehabilitation of mangrove ecosystems: an overview. Biology and Fertility of Soils33:265-278.

Jones, D. A. 1984.

Crabs of the mangal ecosystem. In: Hydrobiology of the Mangal (F. D. Por \& I. Dor eds), pp.89-109. W. Junk Publishers, The Hague.

Lee, S. Y. 1999.

The effect of mangrove leaf litter enrichment on macrobenthic colonization of defaunated sandy substrates. Estuarine, Coastal and Shelf Science 49:703-712.

Macintosh, D. J. 1984.

Ecology and productivity of Malaysian mangrove crab populations (Decapoda: Brachyura). In: Proceedings of the Asean Symposium on mangrove Environment Research \& Management (E. Soepadmo, A. N. Rao, \& D. J. Macintosh eds), pp. 354-377. University of Malaya and UNESCO.

Macintosh, D. J. 1988.

The ecology and physiology of decapods of mangrove swamps. In: Aspects of Decapod Crab Biology. (A.A. Fincham \& P.S. Rainbow eds), pp. 315-341. Symposia of the Zoological Society, London.

Macnae, W. 1968.

A general account of the flora and fauna of mangrove swamps and forests on the Indo-West-Pacific Region. Advances in Marine Biology 6:73-270.

Olafsson, E. \& S. G. M. Ndaro 1997.

Impact of the mangrove crabs Uca annulipes and Dotilla fenestrata on meiobenthos. Marine Ecology Progress Series1 58:225-231.

Pinto, L. 1984.

Mangroves of Sri Lanka. A booklet published by Natural Resources, Energy and Science Authority of Sri Lanka, Colombo. $54 \mathrm{pp}$.

Plaziat, J.C. 1984.

Mollusk distribution in the mangal. In: Hydrobiology of the mangal. (F. D. Por, \& I. Dor eds), pp. 111-143. W. Junk Publishers, The Hague.

Robertson, A.I. 1986.

Leaf-burying crabs: their influence on energy flow and export from mixed mangrove forests (Rhizophora spp.) in northeastern Australia. Journal of Experimental Marine Biology and Ecology 102:237-248.

Robertson, A.I. 1991.

Plant-animal interactions and the structure and function of mangrove forest ecosystems. Australian Journal of Ecology 16:433-443.

Sasekumar, A. 1974. 
The distribution of macrofauna on a Malayan mangrove shore. Journal of Animal Ecology 43:51-69.

Skilleter, G.A. \& S. W arren 2000.

Effects of habitat modification in mangroves on the structure of mollusk and crab assemblages. Journal of Experimental Marine Biology and Ecology 244: 107-129.

Smith III, T.J. K.G. Boto, S.D. Frusher, \& R.L. Giddins 1991.

Keystone species and mangrove forest dynamics: the influence of burrowing by crabs on soil nutrient status and forest productivity. Estuarine Coastal and Shelf Science 33:419-432.

Tirmizi, N. M, N. Ghani \& K.Khan 1986.

Mangrove Crabs of Karachchi, Pakistan. Agriculture Research Council, Islamabad.

W alkley, A. \& I. A. Black 1934.

An examination of degtjareff method for determining soil organic matter and a proposed modification of the chromic acid titration method. Soil Science 37:29-37.

Zar, J. 1995

Biostatistical analysis. 3rd ed. Prentice-Hall. Englewood Cliffs, NJ. USA. 